\title{
SKIN INJURIES RELATED TO THE USE OF PERSONAL PROTECTION EQUIPMENT IN HEALTHCARE PROFESSIONALS
}
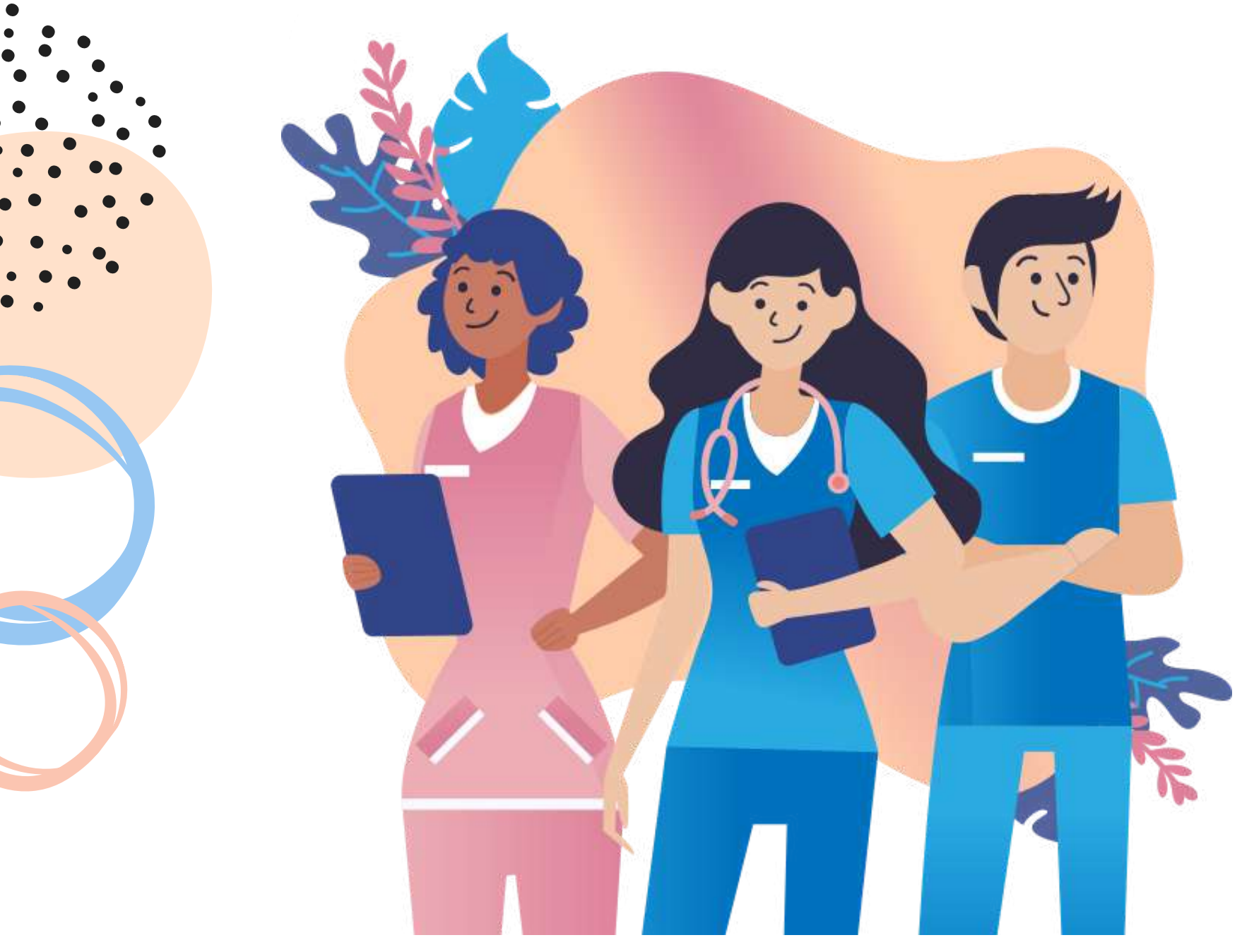

Prevention Strategies for facing the Covid-19 Pandemic 
This work is licensed under the CC BY-NC-ND attribution, allowing the download and sharing as long as the source is mentioned, but without altering it in any way or using it for commercial purposes.

\section{Cataloging in Publication (CIP) \\ "Wanda de Aguiar Horta" Library \\ Universidade de São Paulo, Escola de Enfermagem (School of Nursing of the University of São Paulo}

\section{Ramalho, Aline de Oliveira}

Skin injuries related to the use of personal protective equipment in health professionals: prevention strategies for facing the Covid-19 Pandemic / Aline de Oliveira Ramalho, et al.; reviewers Vera Lucia Conceição de Gouveia Santos, Sônia Regina Pérez Evangelista Dantas; graphic design and illustrations Talita dos Santos Rosa. - São Paulo: GPET, SOBEST, 2020.

$17 \mathrm{p}$.

https://doi.org/10.30886/ManualMDRPICovid19_EN

1. Pressure Injury. 2. Equipment and supplies.

3. Disease prevention. 4. Health professionals.

5.Nursing. 6. Coronavirus. I. Title.

Catalog card prepared by Fabiana Gulin Longhi (CRB-8: 7257)

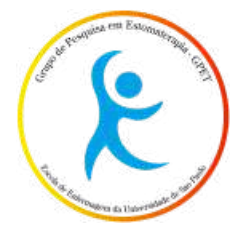

Research Group in Stomal Therapy: ostomy, acute and chronic wounds, and urinary and fecal incontinence - GPET

(Grupo de Pesquisa em Estomaterapia)

419 Dr. Enéas Carvalho de Aguiar Ave, Cerqueira César, Sao Paulo, SP.

Postal Code: 05403-000 - Brazil.

Telephone: (+55 11) 3061-8878
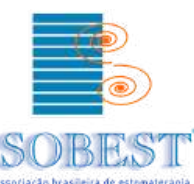

Brazilian Association of Enterostomal Therapy - SOBEST

35 Antonio de Godoi St, 102, República, Sao Paulo, SP.

Postal Code: 01034000 - Brazil.

Telephone: (+55 11) 30810659 


\section{REVIEWERS}

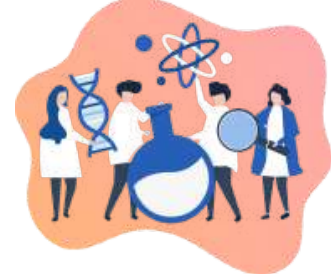

VERA LUCIA CONCEIÇÃO DE GOUVEIA SANTOS

SÔNIA REGINA PÉREZ EVANGELISTA DANTAS

\section{AUTHORS}

ALINE DE OLIVEIRA RAMALHO

TALITA DOS SANTOS ROSA

CAROL VIVIANA SERNA GONZÁLEZ

PAULA DE SOUZA SILVA FREITAS

PAULA CRISTINA NOGUEIRA

TALITA DOS SANTOS ROSA

Designed Vetores by ${ }^{\circledR}$ Freepik

\section{TRANSLATION PORTUGUESE TO ENGLISH}

MARYKE WIJMA

\section{REALIZATION}

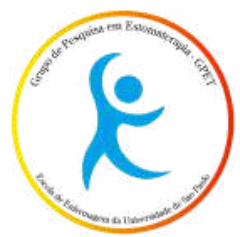

Research Group in Stomal Therapy: ostomy, acute and chronic wounds, and urinary and fecal incontinence - GPET

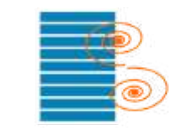

SOBESTI

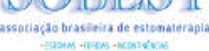

Brazilian Association of Enterostomal Therapy -SOBEST

\section{SUPPORT}

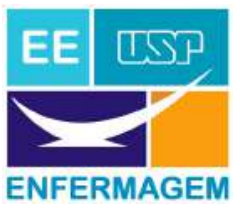

Universidade de São Paulo, Escola de Enfermagem -EEUSP

(School of Nursing of the University of São Paulo)

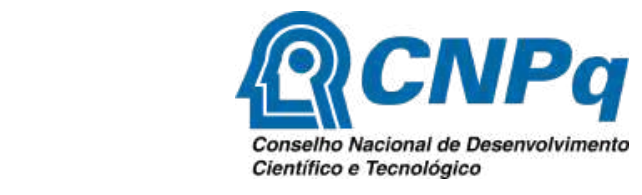

Brazilian National Research Council - CnPq

(English translation)

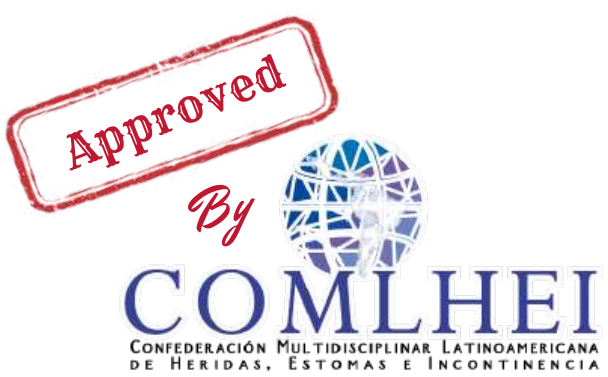

Latin American Multidisciplinary Confederation for Wounds,

Ostomies and Incontinence care (COMLHEI) 


\section{Presentation}

In the current scenario that we are living in, with the COVID-19 pandemic, many health professionals have presented skin lesions due to the use of Personal Protective Equipment (PPE). Among these injuries, there are Medical Device-Related Pressure Injuries (MDRPI), mainly caused by the constant use of PPE, mainly the N-95/FFP2 or equivalent respirators and glasses, which are essential for professionals who provide direct medical assistance to patients with suspicion and/or confirmation of COVID19.

The "MDRPI in health professionals in times of pandemic" are present in all contexts of care and the media has released several images. Such injuries can be painful, cause discomfort and constitute a gateway for infections, in addition to impacting the quality of patient care and the quality of life of professionals.

Therefore, care is essential to maintain the integrity of the health professional's skin. In this context, the Research group in Stomal Therapy Nursing: stomas, acute and chronic wounds, and urinary and anal incontinence, from the University of São Paulo School of Nursing (GPET-EEUSP), in partnership with the Brazilian Association of Enterostomal Therapy (SOBEST), disclose this handbook with the main recommendations for the prevention of MDRPI in health professionals.

In order to write this handbook aimed at Health Professionals, the scientific evidence extracted from national and international Consensus and Guidelines was reviewed, and the main measures for skin protection that can be adopted by health professionals caring for suspected or confirmed COVID-19 patients, were selected. Such recommendations, however, can be complemented with new guidelines as new studies are developed and published since scientific evidence is scarce in the context of the current scenario.

In addition to the recommendations for the protection of the skin of health professionals to prevent MDRPI, this handbook provides important information regarding the COVID-19 pandemic in a national and worldwide context, the use of PPE and self-care measures and the preservation of mental health. The illustrative figures and photos stand out throughout the document.

Enjoy!

\section{Prof. Dr. Paula Cristina Nogueira Prof. Dr. Vera Lúcia Conceiçao de Gouveia Santos}




\section{Sumonary}

\section{2}

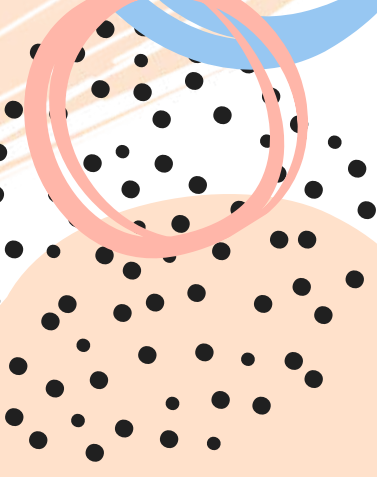

The pandemic in Brazil and in the world

Health professionals facing the COVID-19 pandemic

The use of PPE and skin injuries

The Enterostomall Therapy Nurse

(ETN) watchful eye

Skin protection measures for healthcare professionals

Self-care measures and the preservation of mental health for health professionals

Finall message

References

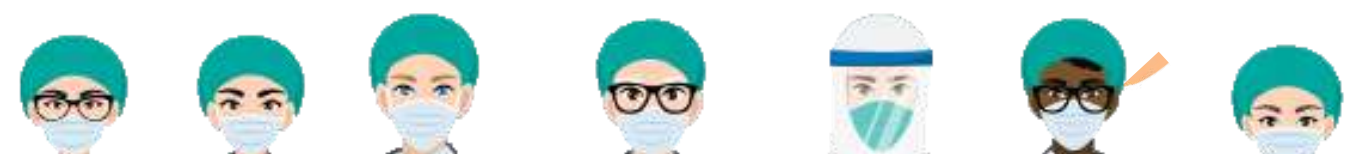

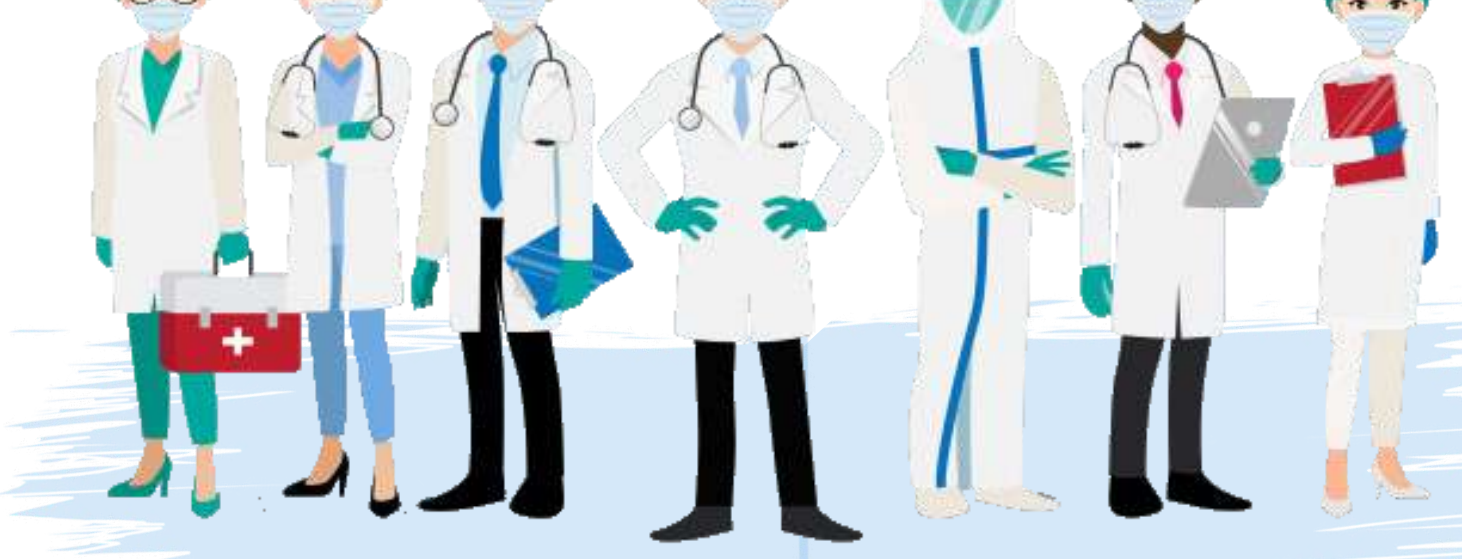



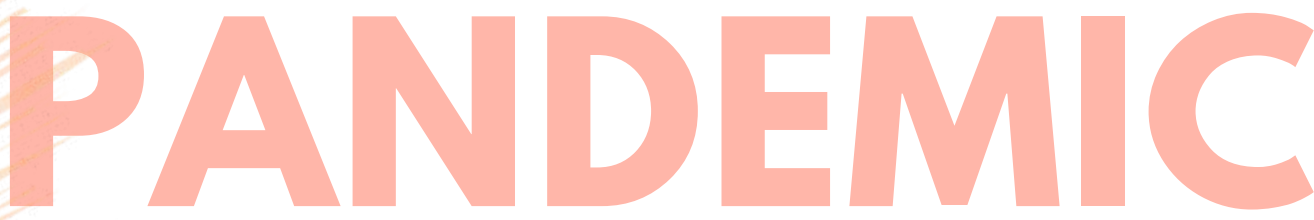

The World Health Organization (WHO) declared the new coronavirus pandemic: SARS-COV-2, on March 11, 2020.

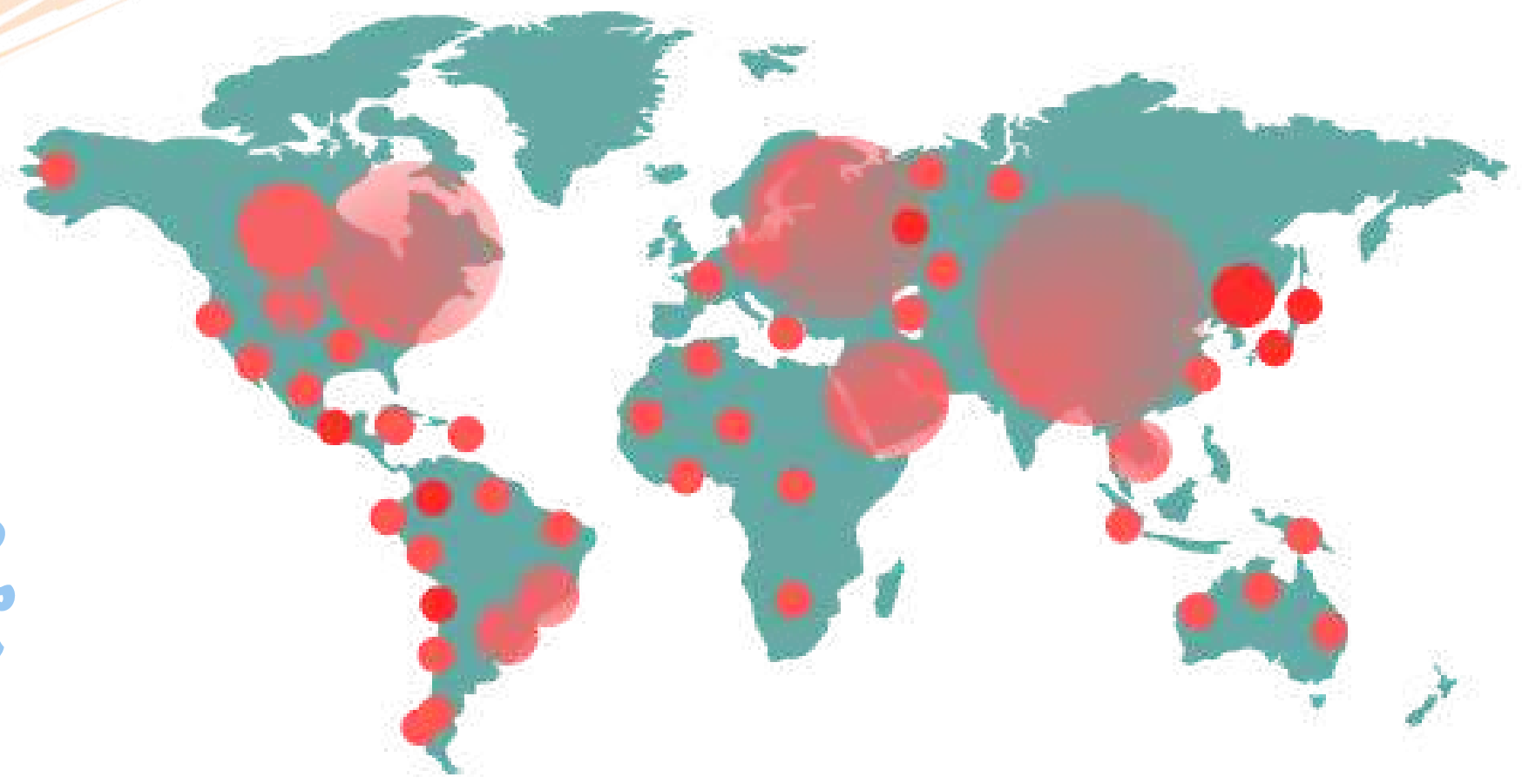

\section{The pandemic in Brazil and in the world}

Recently, in December 2019, an outbreak of pneumonia started in Wuhan-Hubei, China. This infection was caused by a new betacoronavirus of the severe acute respiratory syndrome (SARS-COV-2). This disease was called COVID-19 (Li et al, 2020). This local outbreak spread rapidly across the world, reaching over 200 countries. On March 11, 2020, the World Health Organization (WHO) declared a pandemic and constituted a Public Health emergency of international importance, the Organization's highest alert level (WHO, 2020; Dong, 2020a).

In Brazil, the first COVID-19 case was confirmed on February 28, 2020. Since then, cases have increased exponentially due to the high transmission capacity of "SARS-COV-2" (WHO, 2020a; Dong, 2020).
THE MANAGEMENT OF PEOPLE AFFECTED

BY SARS-COV-2 DIFFERENTIATES IN ACCORDANCE TO THE PRESENTED SYMPTOMS:

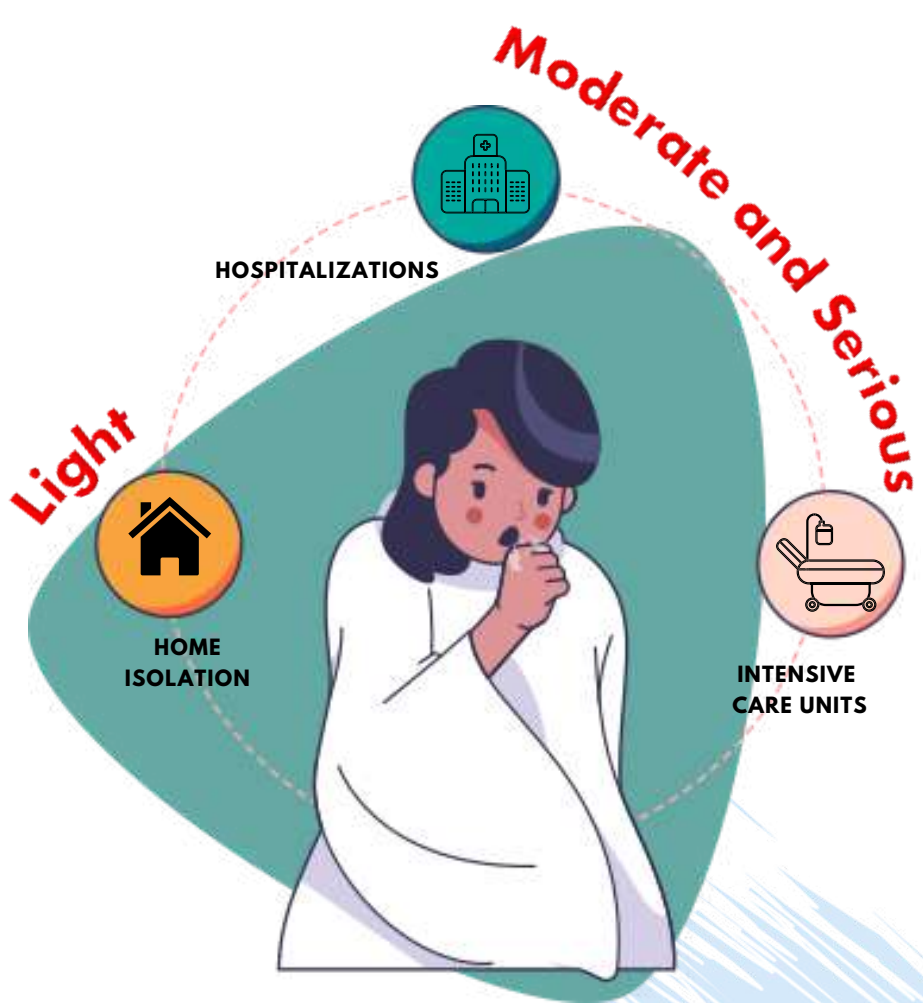




\section{HEALTH PROFESSIONALS FACING}

THE COVID-19 PANDEMIC

Hand hygiene and antisepsis, and the use of personal protective equipment (PPE) such as masks, glasses, gloves, caps and laboratory coats by health professionals, are the main individual protection measures when assisting people with COVID-19 (WHO, 2020a; GVIMS/GGTES/ ANVISA, 2020).

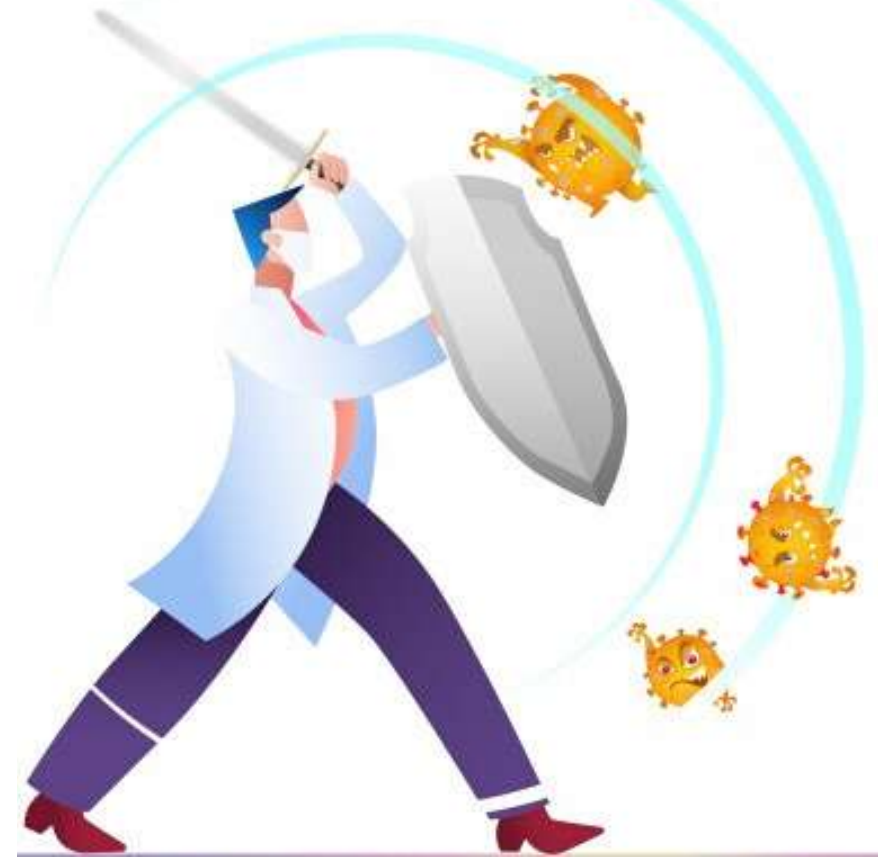

\section{The World Health Organization}

\section{recommends the use of PPE:}

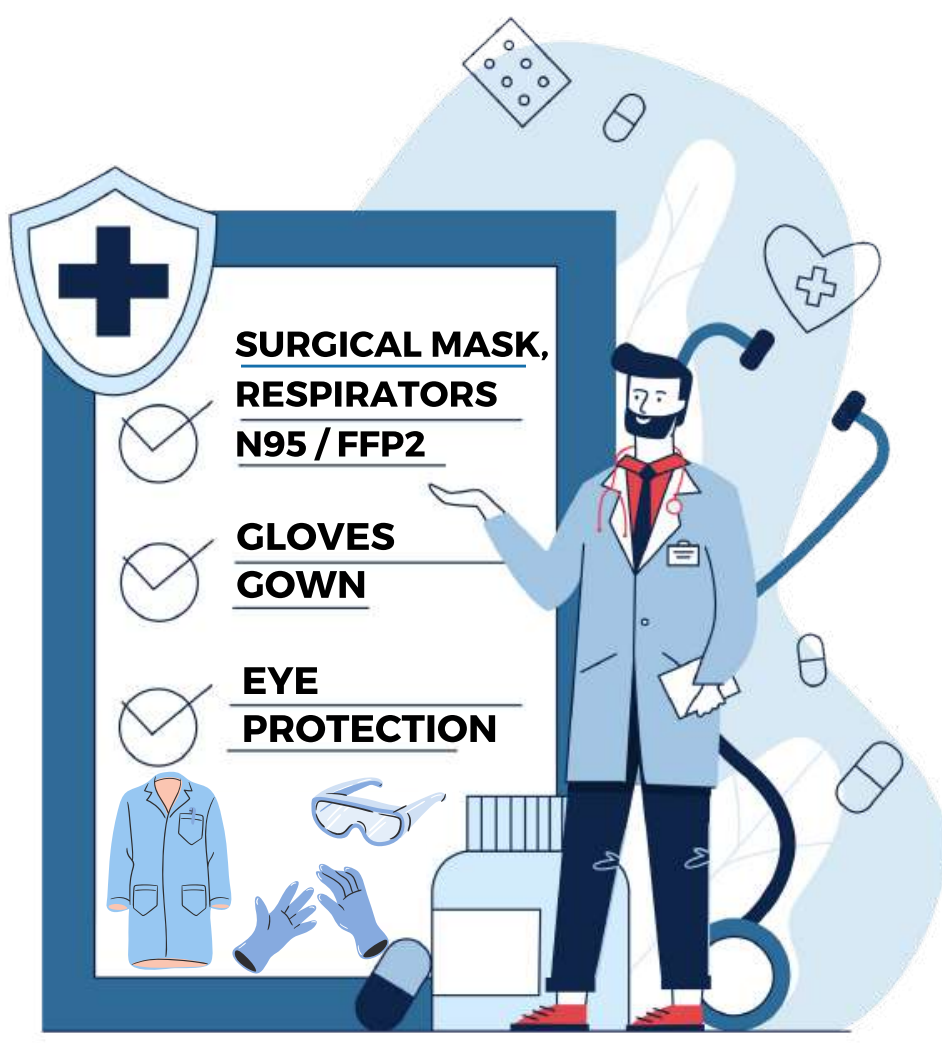

For health professionals who take direct care of patients, the use of a surgical mask is essential. For procedures that generate aerosols such as intubation, non-invasive ventilation, aspiration, among other precautions, the WHO and the National Health Surveillance Agency (Agencia Nacional de Vigilância Sanitária - ANVISA) recommend the use of N 95/FFP2 or equivalent respirators. In addition, the Brazilian Society of Intensive Medicine Care recommends the constant use of this type of protection in intensive care environments where patients with a confirmed and/or suspicion status of COVID-19 are being treated (WHO, 2020a; AMIB, 2020; GVIMS/GGTES/ANVISA, 2020). 


\section{YTHE USE OF PPE AND SKIN}

INJURIES
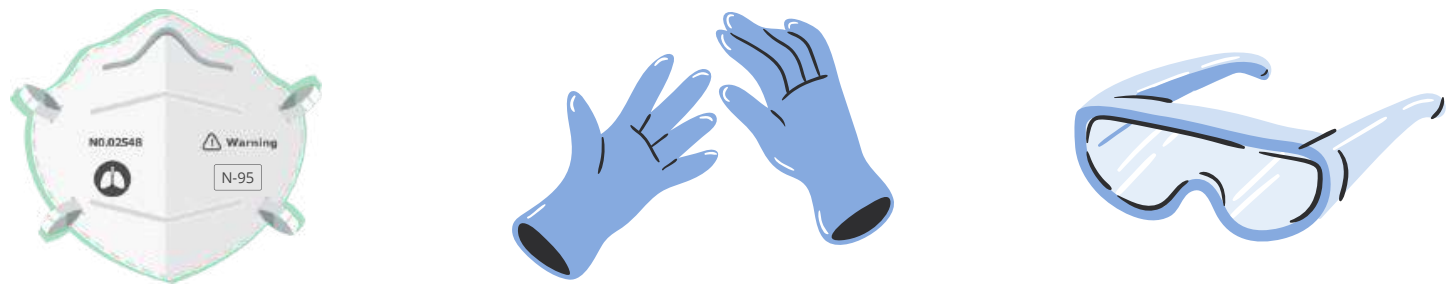

The $\mathrm{WHO}$ recognizes the need to wear a respiratory protection mask, however, it draws attention to the fact that these masks should not be worn for more than 4 hours in a row, due to the discomfort caused by them (WHO, 2020a).

The wearing of PPE and hand hygiene are essential for occupational protection, however, due to the SARS-COV-2 pandemic, the need for frequent hand hygiene and the wearing of gloves has increased the risk of dermatitis and dermatosis, and may cause erythema, dryness, flaking, cracking, itching, secondary infections and worsening of pre existing skin diseases. The prolonged wear of masks, especially N-95/FFP2 respirators and glasses, may increase the risk of pressure injury and/ friction on the face. (Galetto. Et al, 2019; Darlenski and Tsankov, 2020).
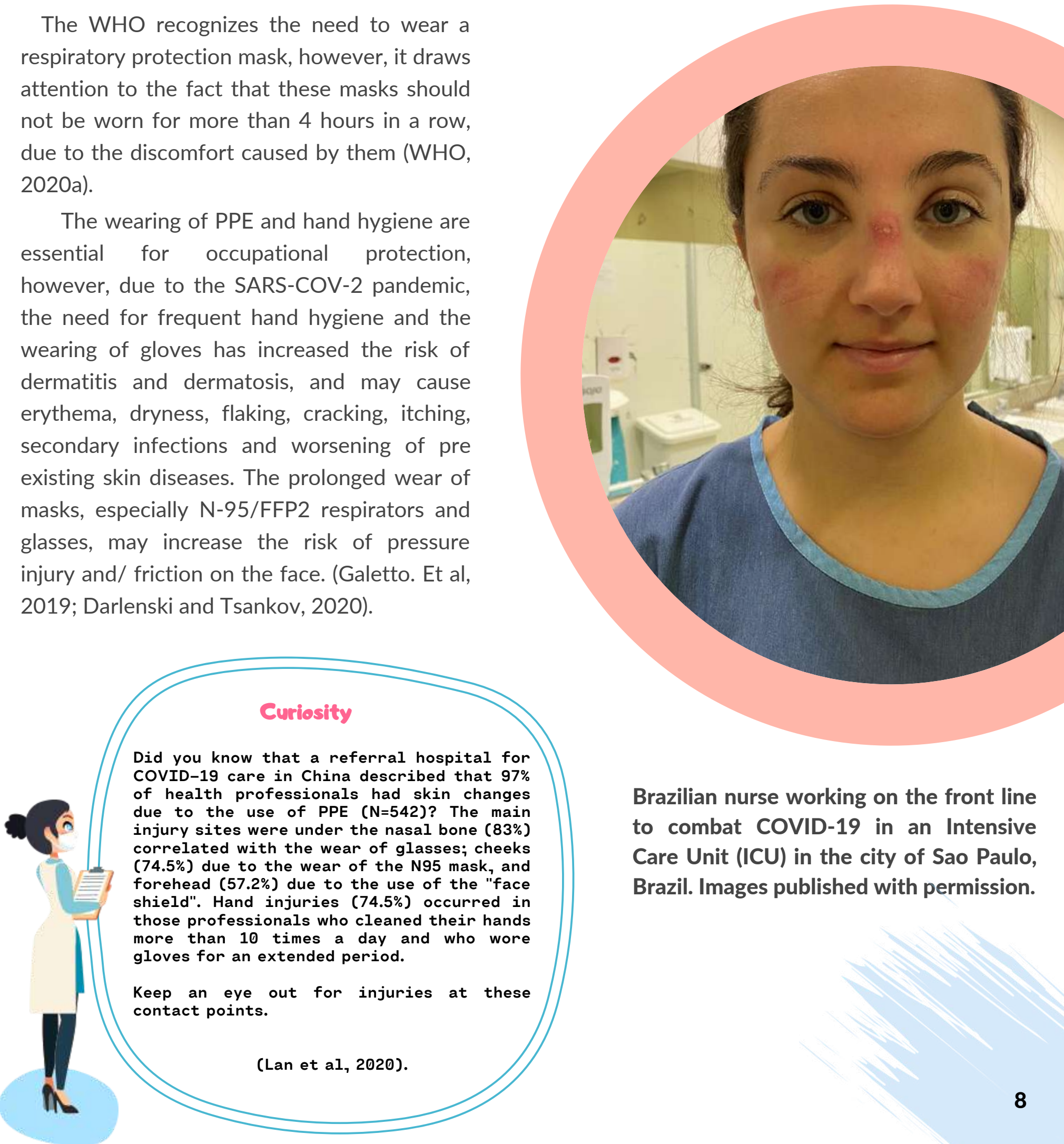

Brazilian nurse working on the front line to combat COVID-19 in an Intensive Care Unit (ICU) in the city of Sao Paulo, Brazil. Images published with permission. 


\section{SKIN PROTECTION MEASURES FOR HEALTHCARE}

\section{PROFESSIONALS}

Considering the importance and necessity of frequent use of PPE at the time of the pandemic, this handbook aims to contribute to the self-care guidelines for maintaining the integrity of the skin of health professionals. The proposed skin protection measures were based on scientific evidence from recent international and national studies, consensus and guidelines (Gefen, et al. 2020; NPIAP, 2020; Yan et al, 2020; Lan et al, 2020; WOCN, 2020; Galetto. et al, 2019; EPUAP, NPUAP, PPPIA, 2019; Yamada, 2015)

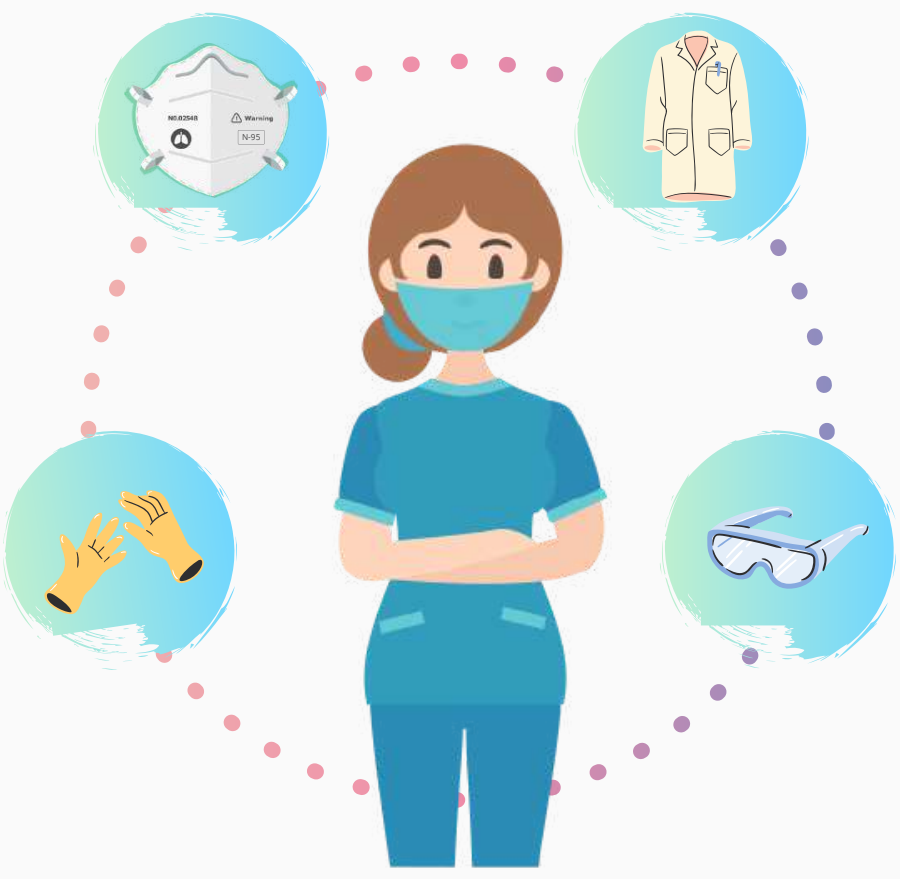

\section{So, let's go to the protection measures:}

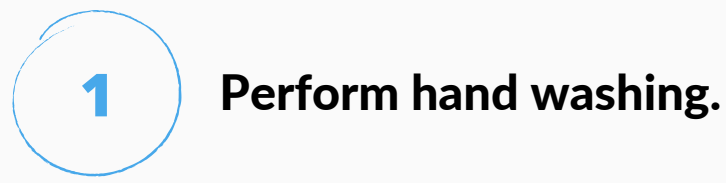

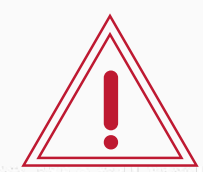
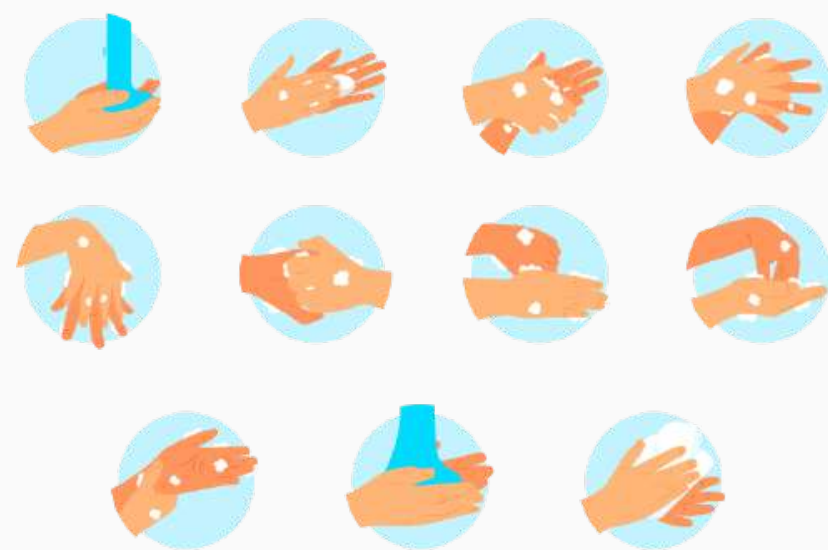

(GVIMS/GGTES/ANVISA, 2020)

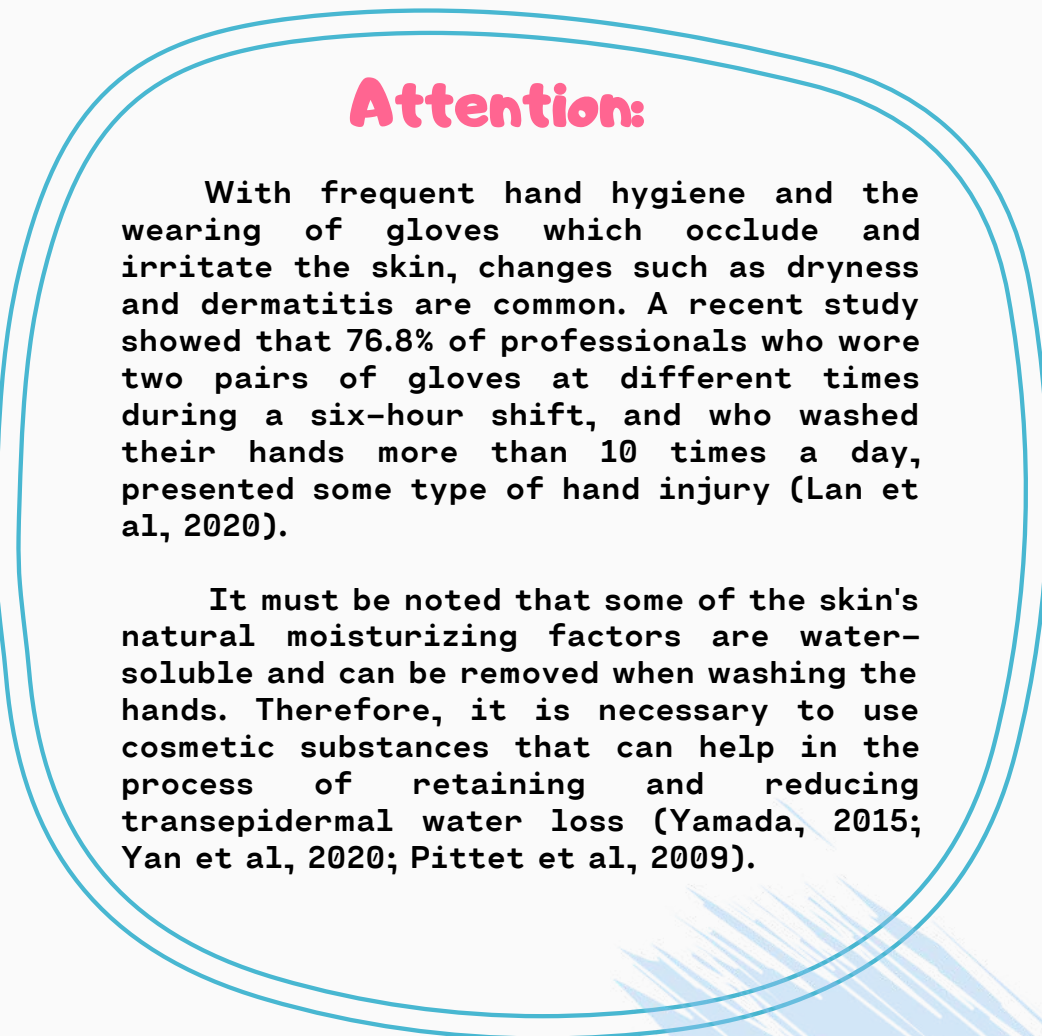




\section{SKIN PROTECTION}

Sanitize the skin with liquid soap with a slightly acidified pH (compatible with the skin).
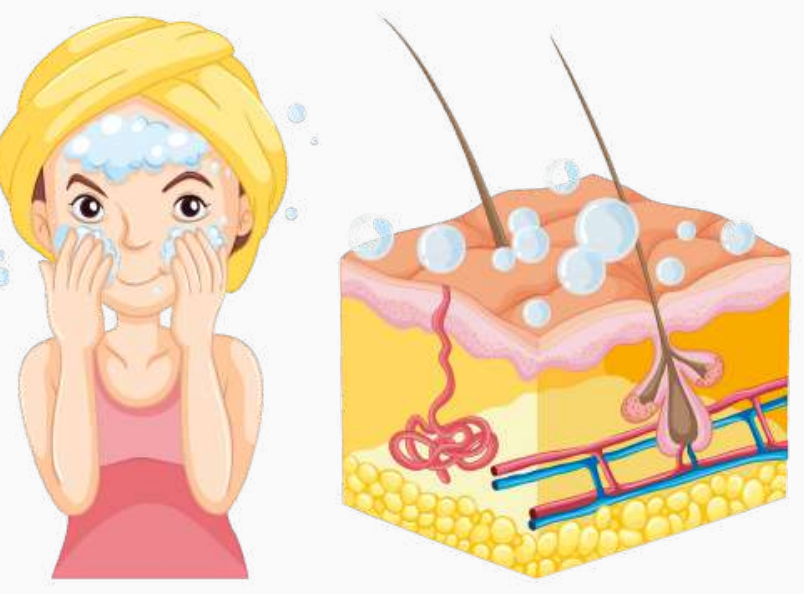

(NPIAP, 2020; Yamada, 2015; Yan et al, 2020)

Moisturize the skin daily, especially the hands and face, with cosmetic products with a balanced composition of humectants and active hydrating substances that are quickly absorbed and dried. For the face, it is important to choose products that do not prevent the fixation of adhesives used as an interface for skin protection, and that do not affect the correct positioning of the masks and glasses.

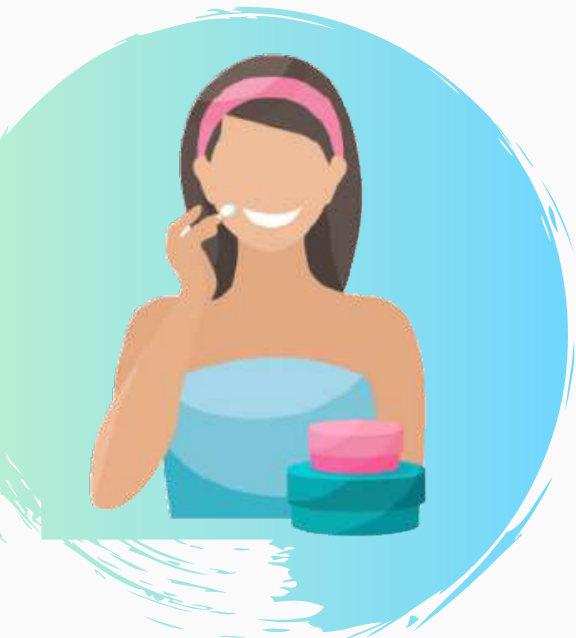

PD: IF DRYNESS OCCURS, INCREASE THE FREQUENCY OF HYDRATION.
Due to the absence of scientific evidence and uncertainties about the risk of SARSCOV-2 fixing on the skin, it is essential to carry out studies to assess the chemical interaction between the components of moisturizers and the virus. 


\section{SKIN PROTECTION

Protect the skin in the area where the mask/respirator and glasses are attached, when worn for a long period, especially in the regions shown below or where pressure, friction and shear forces are identified, ensuring the correct fit of the mask/respirator and glasses to the face.

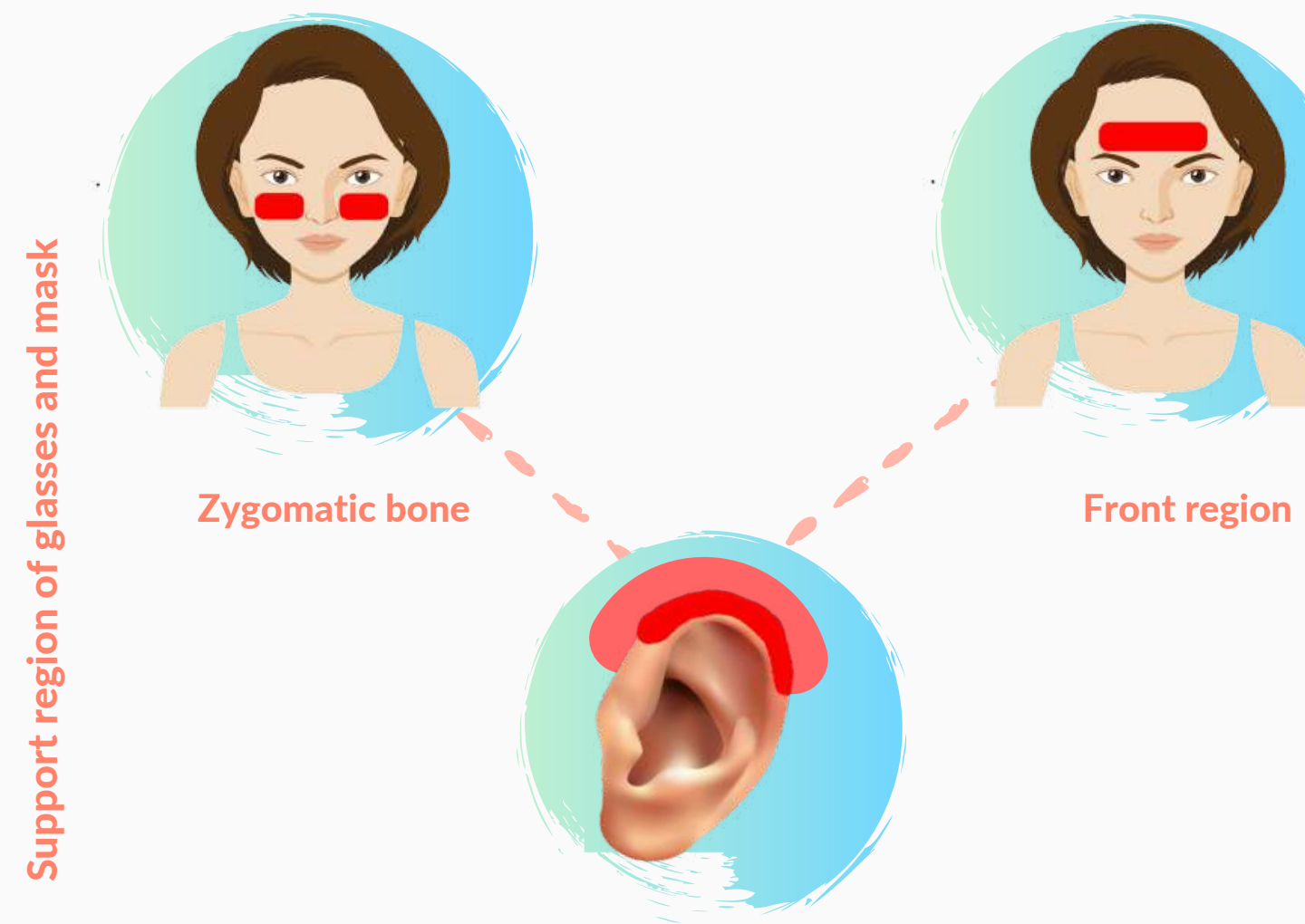

Auricular helix and back of ear

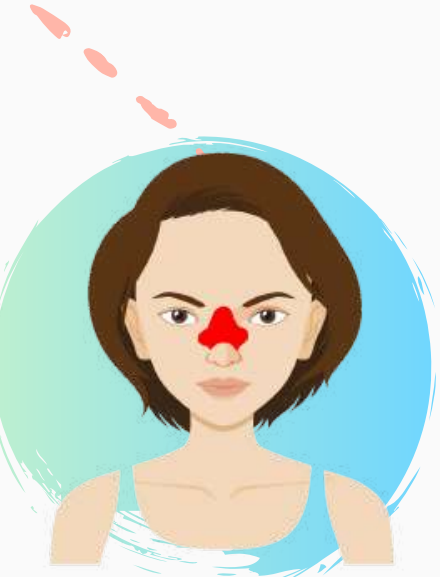

Nasal bone

PS: Apply prophylactic coverage as an interface between the skin and the device to reduce the risk of injury: polyurethane foam, silicone, transparent film or hydrocolloid plates, thin or extra thin, so as not to compromise the mask/respirator seal on the skin. 


\section{SKIN PROTECTION

Program pressure relief minutes by establishing periods for removing the mask/respirator and glasses at least every 2 hours, avoiding contamination of the hands when manipulating the outer layers of these PPE.

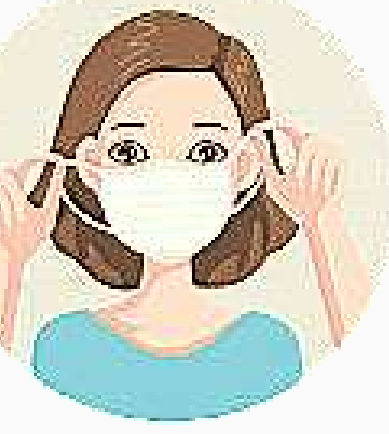

Remove the mask/respirator as soon as possible following the appropriate removal protocol. Do not touch the front of the mask, since it is considered the most contaminated area of the device.

PS: Although you protect the skin, the protective films or creams do not provide pressure relief, even contributing to protection against humidity and friction.

(Udwadia, 2020; Yan et al, 2020; EPUAP, NPUAP, PPPIA, 2019)

Inspect the skin after using PPE and look out for signs and symptoms:

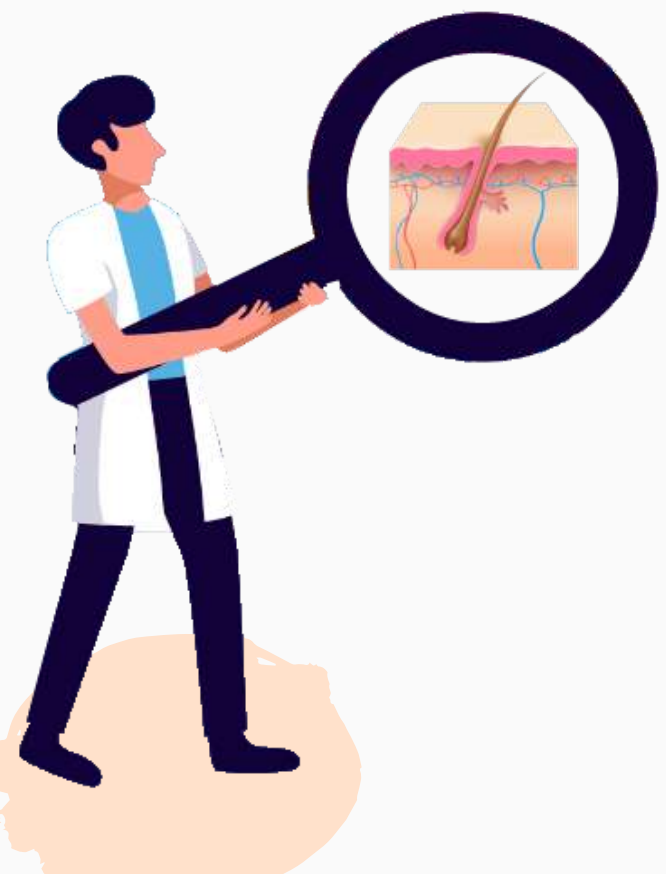

- Pain

- Itching

- Hyperemia

- Dryness

- Phlyctena

- Lesions 


\section{SKIN PROTECTION SURES FOR HEALTHCARE PROFESSIONALS}

Treat, protect and avoid the wear of a mask/respirator and glasses on areas of skin lesions, eczema or hyperemia.
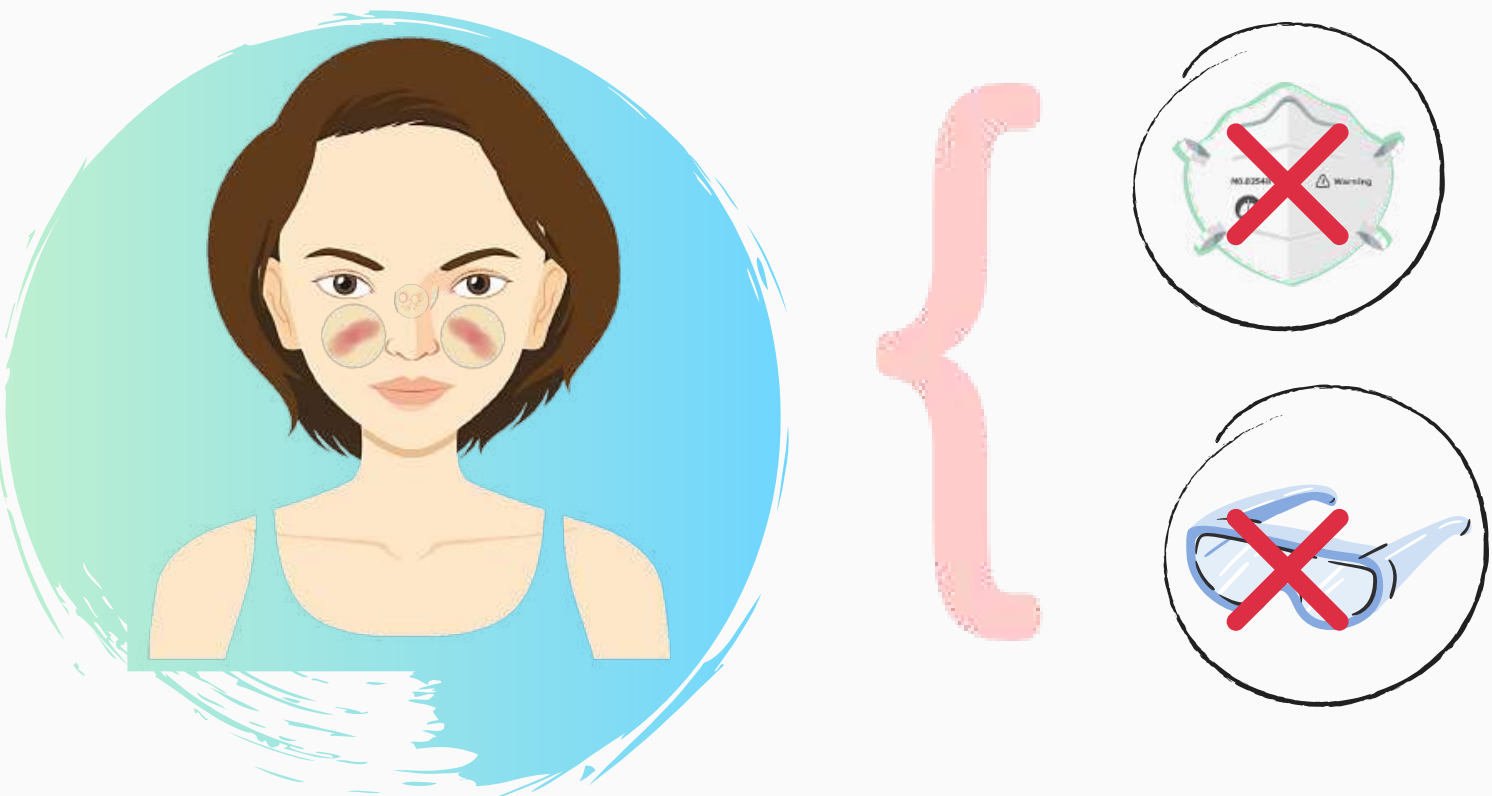

PS: In the case of injuries, treatment following an institutional protocol should be conducted with an emphasis on antimicrobial cleaning and reducing the risk of contamination.

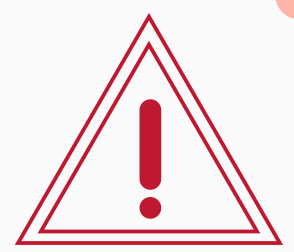

These are recommendations from ETN, based on the literature available thus far. However, due to the littleexplored panorama of the new SARS-COV-2 coronavirus and with the advancement of the scientific literature, they may be altered or complemented.

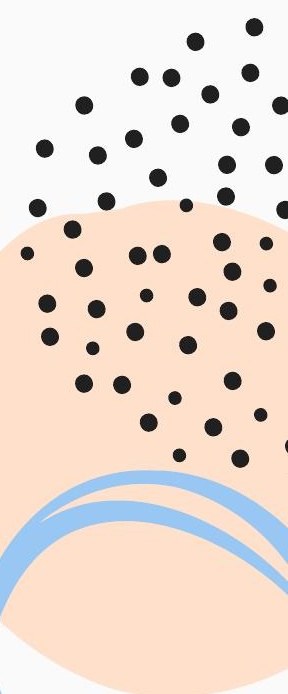




\section{SELE-CARE MEASURES A

The insecurity and fear caused by the COVID19 pandemic, alarming epidemiological data, risks of disease acquisition and transmission, loss of patients, exhausting working hours, frequent use of PPE and risks of skin damage, can negatively influence the mental health and psychosocial well-being of health professionals (WHO, 2020b). A Chinese study showed that $70 \%$ of health professionals at the front line in Wuhan had extreme levels of stress, with symptoms of depression (50\%), anxiety (44\%) and insomnia (34\%) (Lai et al, 2020).

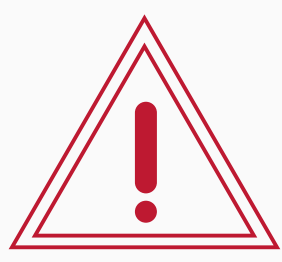

Remember that maintaining mental health is essential in stressful times. Look for a specialist, if necessary!

\section{Exercise self-care and practice activities that help you positively:}

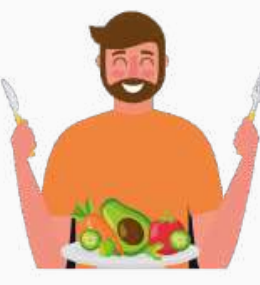

\section{EAT AND} HYDRATE WELL

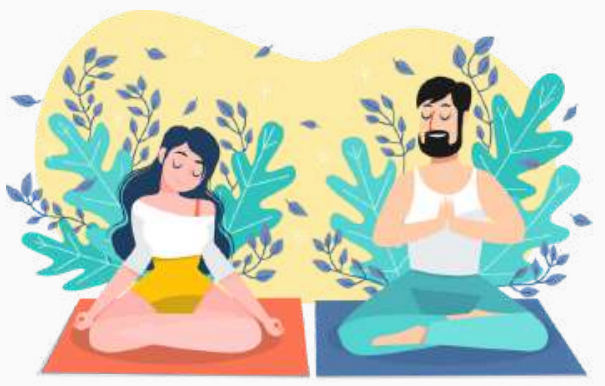

PRACTICE OR EXERCISE YOUR FAITH

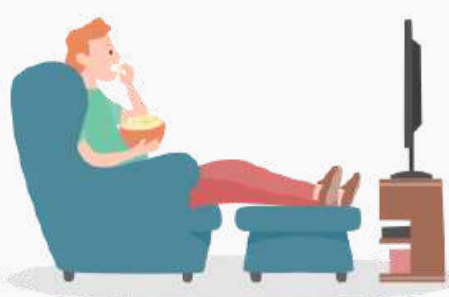

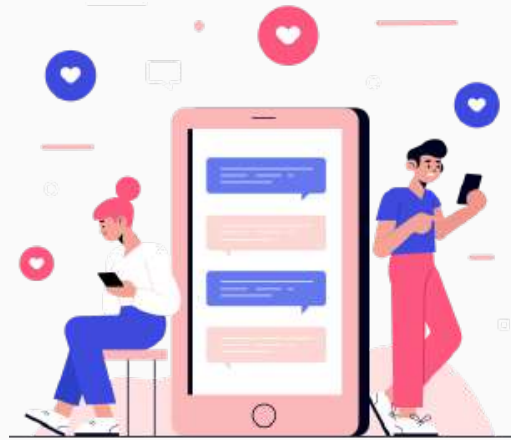

KEEP SOCIAL CONTACT, EVEN AT DISTANCE 


\section{Final message}

By: RN. Talita dos Santos Rosa

\section{To health professionals who are working hard to combat COVID-19,}

We are facing one of humanity's greatest challenges. The perplexity and uncertainty in the face of a bleak world panorama confirmed by statistics on morbidity and mortality leave us fearful and lost. This is all new and scary. Quickly, like never before, the world took on another form, we slowed down, we got paralyzed. Habits and behaviours were reassessed. Handshakes, hugs and kisses became offensive ... we changed. Our vulnerabilities were exposed and what was once an absolute truth and priority has ceased to be. We perceive ourselves to be fragile but, at the same time, we have become strong in the midst of the pandemic. We discovered our importance in the whole, we saw ourselves in the same boat and we will only reach the shore if we accept our selfishness, weaknesses and paddle together.

You, the healthcare professional, are facing thousands of desperate and hopeful looks in search of treatment, cure, reception and assistance. As Pope Francis said in his last speech:

"The lives of thousands of people are being designed and supported by ordinary people (usually forgotten), who do not appear in the headlines of newspapers and magazines, nor on the big catwalks, but, who today are undoubtedly writing the decisive events of our history: doctors, nurses, supermarket workers, cleaning staff, curators, transporters, police forces, volunteers, priests, nuns and many - but many - others who understood that no one is saved alone".

Right now, some priorities are being revised, our projects reformulated. What used to make sense to science is now unclear. It is up to you to be strong without putting yourself in the place of invincibility and heroism. We are human, we have been in the front line, in the field of health for a long time, maybe we just didn't have everyone's attentive eyes. Recognized for caring for others, for being selfless. However, in this extremely delicate moment, where your presence is necessary, it is essential that you look at yourself, exercise self-care and preserve your health, so that you can collaborate with the assistance to society effectively.

It was up to you to lead the fight against the pandemic, to embrace the adversities imposed with faith and courage. It will be up to you to exercise your profession as always, with dedication, ethics, responsibility and donation. However, do not forget how important and necessary you are to everyone ... So, BE CAREFUL. The pandemic will pass, support your colleagues, support your institution, share creative solutions, stay positive, pay attention to hygiene and protection measures. We are all together in the fight against COVID-19. All of this will soon pass. Let us maintain awareness about the relevance of public health systems and about us, health professionals!

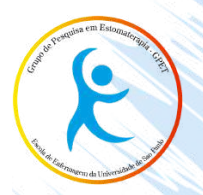


Associação de Medicina Intensiva Brasileira (AMIB). Na UTI, a segurança da equipe é fundamental! São Paulo: AMIB; 2020. [citado em 21 mar 2020]. Disponível em: https://www.amib.org.br/fileadmin/user_upload/amib/2020/marco/ 07/COVID-19_seguranca_equipev14032020_18h16.pdf

Agencia Nacional de Vigilância Sanitaria (GVIMS/GGTES/ANVISA), Orientações para serviços de saúde: medidas de prevenção e controle que devem ser adotadas durante a assistência aos casos suspeitos ou confirmados de infecção pelo novo coronavírus (SARs-COV-2). Nota técnica GVIMS/GGTES/ANVISA nº 04/2020 - 31.03.2020. [citado em 21 mar 2020]. Disponivél em: http://portal.anvisa.gov.br/documents/33852/271858/Nota+T\%C3\%A9cnica+n+042020+GVIMS-GGTES-ANVISA/ab598660-3de4-4f14-8e6f-b9341c196b28

Caliri MHL, Santos VLCG, Mandelbaum MHS, Costa IG. Classificação das Lesões por pressão - Consenso NPUAP 2016 Adaptada Culturalmente para o Brasil. São Paulo: SOBEST/SOBENDE; 2016. [citado em 21 mar 2020]. Disponível em: http://www.sobest.org.br/textod/35.

Darlenski R, Tsankov N. Covid-19 pandemic and the skin - What should dermatologists know? Clin Dermatol [Internet]. 2020 Mar 24 [[citado em 31 mar 2020]; Disponível em: https://linkinghub.elsevier.com/retrieve/pii/S0738081X20300 493

Dong E, Du H, Gardner L. An interactive web-based dashboard to track COVID-19 in real time [published online ahead of print, 2020 Feb 19]. Lancet Infect Dis. 2020;S1473-3099(20)30120-1. [citado em 31 mar 2020]. Disponível em: https:// doi:10.1016/S1473-3099(20)30120-1.

European Pressure Ulcer Advisory Panel. National Pressure Injury Advisory Panel. Pan Pacific Pressure Injury Alliance. Prevention and Treatment of Pressure Ulcers: Quick Reference Guide [Internet]. Emily Haesler, editor. Prevention and Treatment of Pressure Ulcers/Injuries: Quick Reference Guide. 2019. [citado em 24 mar 2020] Disponível em: https://www.epuap.org/download/11182/.

Galetto SGS, Nascimento ERP, Hermida PMV, Malfussi LBH. Medical Device-Related Pressure Injuries: an integrative literature review. Rev Bras Enferm. [Internet]. Scielo.br. 2020 [citado em 1 abril 2020] Disponível em: http://www.scielo.br/pdf/reben/v72n2/pt_0034-7167-reben-72-02-0505.pdf.

Gefen A, Alves P, Ciprandi G, Coyer F, Milne CT, Ousey K, et al. Device-related pressure ulcers: SECURE prevention. J Wound Care [Internet]. 2020 Feb 1;29(Sup2a):S1-52. [citado em 31 mar 2020]. Disponivel em: https://doi.org/10.12968/jowc.2020.29.Sup2a.S1.

Lai J, Ma S, Wang Y, Cai Z, Hu J, Wei N et al. Factors Associated With Mental Health Outcomes Among Health Care Workers Exposed to Coronavirus Disease 2019. 2020. [citado em 1 abril 2020]. Disponível em: https://doi:10.1001/jamanetworkopen.2020.3976.

Lan J, Song Z, Miao X, Li H, Li Y, Dong L, et al. Skin damage among healthcare workers managing coronavirus disease2019. J Am Acad Dermatol [Internet]. 2020 Mar; Disponível em: http://www.ncbi.nlm.nih.gov/pubmed/32171808.

Li Q, Guan X, Wu P, Wang X, Zhou L, Tong Y et al. Early Transmission Dynamics in Wuhan, China, of Novel Coronavirus-Infected Pneumonia. New England Journal of Medicine. 2020;382(13):1199-1207. [citado em 1 abril 2020]. Disponível em: https://doi: 10.1056/NEJMoa2001316.
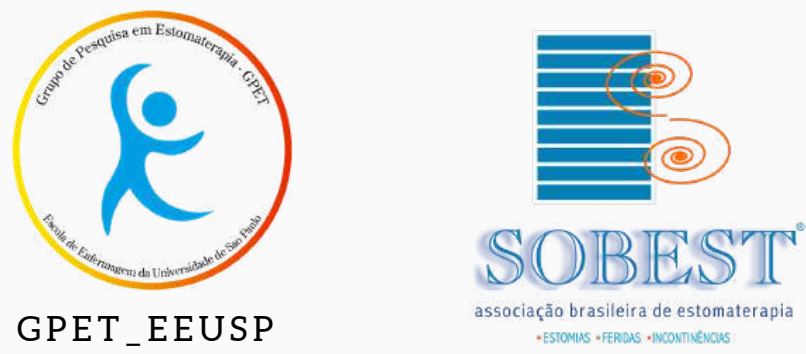
Mills J. Medics left with sore marks all over their skin from coronavirus face masks. Metro [Internet]. 2020 Feb; Disponível em: https://metro.co.uk/2020/02/05/medics-left-sore-marks-skin-coronavirus-face-masks-12188952/

National Pressure Ulcer Advisory Panel (NPUAP). National Pressure Ulcer Advisory Panel (NPUAP) announces a change in terminology from pressure ulcer to pressure injury and updates the stages of pressure injury. Washington: Wound Source; 2016. [citado em 21 mar 2020]. Disponível em: https://www.woundsource.com/blog/national-pressure-ulceradvisory-panel-npuapannounces-change-in-terminology-pressure-ulcer.

National Pressure Injury Advisory Panel (NPIAP). NPIAP Position Statemtents on preventing injury with N95 masks [Internet]. 2020. [citado em 15 abril 2020]. Disponível em:: https://cdn.ymaws.com/npiap.com/resource/resmgr/position_statements/Mask_Position_Paper_FINAL_fo.pdf

Pittet D, Allegranzi B, Boyce J. The World Health Organization Guidelines on Hand Hygiene in Health Care and Their Consensus Recommendations. Infect Control Hosp Epidemiol [Internet]. 2009 Jul 2;30(7):611-22. Available from: http://whqlibdoc.who.int/publications/2009/9789241597906_eng.pdf

Udwadia Z, Raju R. How to protect the protectors: 10 lessons to learn for doctors fighting the COVID-19 Coronavirus. Medical Journal Armed Forces India. 2020;.[citado em 31 mar 2020].

Yamada BFA. Pele: o manto protetor. São Paulo: Andreoli; 2015.

Yan Y, Chen H, Chen L, Cheng B, Diao P, Dong L, et al. Consensus of Chinese experts on protection of skin and mucous membrane barrier for healthcare workers fighting against coronavirus disease 2019. Dermatol Ther [Internet]. 2020 Mar 13 [cited 2020 Mar 31]; Available from: https://onlinelibrary.wiley.com/doi/abs/10.1111/dth.13310

World Health Organization (WHO). Rational use of personal protective equipment for coronavirus disease 2019 (COVID-19): Interim guidance. Genebra: WHO; 2020a. [citado em 21 mar 2020]. Disponível em: https://apps.who.int/iris/bitstream/handle/10665/331215/WHO-2019-nCov-IPCPPE_use-2020.1-eng.pdf

World Health Organization (WHO), COVID-19: Mental health in the age of coronavirus. $2020 \mathrm{~b}$. [citado em 31 mar 2020] Disponível em: hhttps://news.un.org/pt/story/2020/03/1707792.

Wound, Ostomy and Continence Nurses Society (WOCN). Guidance for Maintaining Skin Health When Utilizing Protective Masks for Prolonged Time Intervals. Guidance WOCN; 2020: [citado em 17 abril 2020]. Disponível em: https://cdn.ymaws.com/www.wocn.org/resource/resmgr/docs/Guidance_for_Skin_Health_Upd.pdf

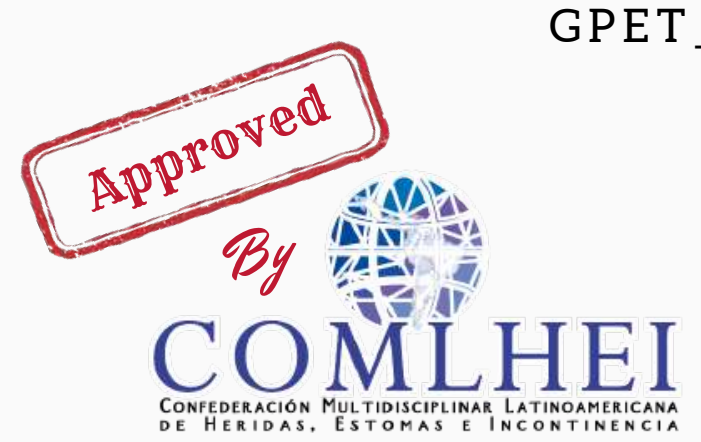

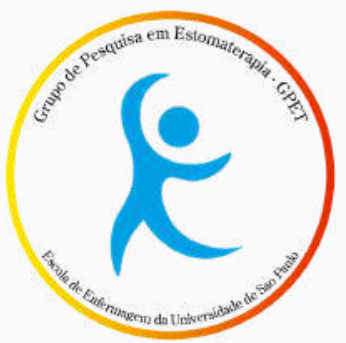

GPET_EEUSP

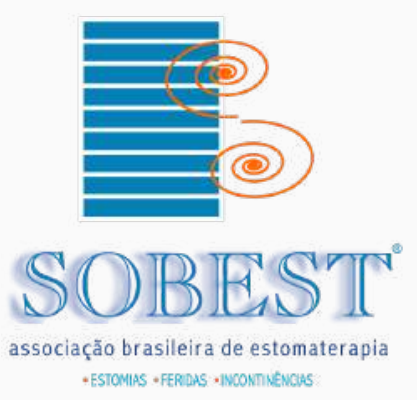

Support:
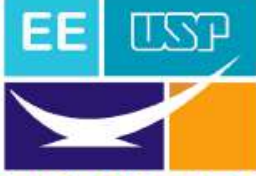